1

\title{
IPSE, a parasite-derived host immunomodulatory protein, is a promising therapeutic for hemorrhagic cystitis
} Running head: IPSE as potential hemorrhagic cystitis therapy

Rebecca S. Zee *, †, Evaristus C. Mbanefo*, †, Loc H. Le†, Luke F. Pennington‡, Justin Odegaard§, Theodore S. Jardetzkył, Abdulaziz Alouffił, Jude Akinwale $\square$, Franco H. Falcone $\square$, Michael H. Hsieh*, †, \#

* Division of Urology, Children's National Medical Center, Washington DC, USA † Bladder Immunology Group, Biomedical Research Institute, Rockville, MD, USA ‡ Department of Structural Biology, Stanford University School of Medicine, Stanford, CA, USA

$\S$ Guardant Health, Redwood City, CA, USA

II Life science and Environment Sector, King Abdulaziz City for Science and Technology (KACST), Riyadh, Saudi Arabia

$\square$ Division of Molecular Therapeutics and Formulation, School of Pharmacy, University of Nottingham, Nottingham, United Kingdom \# The George Washington University, Washington, DC, USA

Correspondence:

Michael H. Hsieh

Children's National Medical Center

111 Michigan Ave NW

Washington, D.C. 20010

Telephone: 202-476-1293

Fax: 202-476-4739

Email:mhsieh@childrensnational.org

Figure count: 6 
bioRxiv preprint doi: https://doi.org/10.1101/400424; this version posted August 25, 2018. The copyright holder for this preprint (which was not certified by peer review) is the author/funder, who has granted bioRxiv a license to display the preprint in perpetuity. It is made available under aCC-BY-NC 4.0 International license.

\section{Abbreviations}

2 CFSE 5-(and 6)-Carboxyfluorescein diacetate succinimidyl ester

3 IPSE Interleukin-4 inducing principle from Schistosoma mansoni eggs

4 MESNA 2-mercaptoethanesulfonic acid

5 NLS Nuclear localization sequence 


\section{Abstract}

2 Chemotherapy-induced hemorrhagic cystitis is characterized by bladder pain and

3 voiding dysfunction caused by hemorrhage and inflammation. Of currently available

4 therapies, prophylactic 2-mercaptoethanesulfonic acid (MESNA) has limited efficacy

5 and cannot treat pre-existing lesions. Therefore, novel therapeutic options to treat

6 hemorrhagic cystitis are needed. We previously reported that systemic administration of

7 the Schistosomiasis haematobium-derived protein H-IPSE ${ }^{\mathrm{H} 06}$ (IL-4-inducing principle

8 from Schistosoma mansoni eggs), is superior to 3 doses of MESNA in alleviating

9 hemorrhagic cystitis. Based on prior reports by others on $S$. mansoni IPSE and

10 additional work by our group, we reasoned that $\mathrm{H}$-IPSE ${ }^{\mathrm{H} 06}$ mediates its effects on

11 hemorrhagic cystitis by binding IgE on basophils and inducing IL-4 expression,

12 promoting urothelial proliferation, and translocating to the nucleus to modulate

13 expression of genes implicated in relieving bladder dysfunction. We speculated that

14 local bladder injection of the $S$. haematobium IPSE ortholog IPSE ${ }^{\mathrm{H} 03}$, hereafter called $\mathrm{H}$ -

$15 \mathrm{IPSE}^{\mathrm{H} 03}$, might be more efficacious in preventing hemorrhagic cystitis compared to systemic administration of IPSE ${ }^{\mathrm{H} 06}$. We demonstrate herein that $\mathrm{H}^{\text {IPSE }}{ }^{\mathrm{H} 03}$ is a

17 promising therapeutic for the treatment of voiding dysfunction and bladder pain in

18 hemorrhagic cystitis. Namely, it attenuates ifosfamide-induced increases in bladder wet

19 weight in an IL-4-dependent fashion. $\mathrm{H}_{\text {-IPSE }}{ }^{\mathrm{H} 03}$ relieves hemorrhagic cystitis-associated

20 allodynia. Finally, H-IPSE ${ }^{\mathrm{H} 03}$ drives increased urothelial cell proliferation. This indicates

21 that IPSE induces bladder healing mechanisms, which suggests that it may be a novel

22 non-opioid analgesic to treat bladder pain syndromes.

23 Key words: IL-4, IPSE, hemorrhagic cystitis, schistosomiasis 


\section{Introduction}

Ifosfamide and other alkylating chemotherapy agents are used in a wide variety of malignancies including leukemias, soft tissue sarcomas, and testis cancer. The liver metabolizes ifosfamide into acrolein, which is excreted in the urine and has a deleterious effect on the urothelium. Hemorrhagic cystitis is characterized by bladder edema, hemorrhage, urothelial denudation, and infiltration of inflammatory cells. This condition affects up to $40 \%$ of ifosfamide-exposed patients, resulting in hematuria, dysuria, bladder spasms, and urinary frequency (9). Hemorrhagic cystitis is a challenging condition to manage, and often requires hospitalization and invasive treatments (16).

Accordingly, strategies to attenuate ifosfamide-induced hemorrhagic cystitis, such as administration of 2-mercaptoethanesulfonic acid (MESNA), bladder irrigation, or hyperhydration often achieve suboptimal protection for patients (16). Despite use of existing therapies, a majority of patients have symptomatic and/or histologic evidence of hemorrhagic cystitis (14). As an alternative to current management approaches, Macedo et al. reported that administration of recombinant interleukin-4 (IL-4) attenuated the effects of ifosfamide in a mouse model of hemorrhagic cystitis (15). The importance of IL-4 in this model was demonstrated by administration of anti-IL4 antibody to ifosfamide-exposed, wild type mice and administration of ifosfamide to IL-4-deficient mice, both of which resulted in worsened hemorrhagic cystitis (20). Interestingly, ifosfamide administration increased endogenous production of IL-4, suggesting the existence of intrinsic regulatory mechanisms to control inflammation in response to ifosfamide (15). However, systemic administration of IL-4 to treat hemorrhagic cystitis 
24 may not be a realistic option due to pleiotropic effects and a short in vivo half-life of this

25 cytokine (18). Therefore, alternative strategies to increase expression of IL-4 would be

26 needed in order to leverage this cytokine for therapeutic treatment of hemorrhagic

27 cystitis.

One alternative may be the interleukin-4 inducing principle from Schistosoma mansoni eggs (IPSE), the most abundant protein secreted by $S$. mansoni eggs. IPSE attenuates inflammation via multiple mechanisms, including binding immunoglobulins to stimulate IL-4 release, sequestering chemokines, and translocating to the nucleus to modulate transcription $(17,19)$. We have previously reported that similar to the $S$. mansoni ortholog of IPSE, M-IPSE, several S. haematobium orthologs, referred

34 hereafter as H-IPSE, bind to IgE on mast cells and basophils and upregulate the expression of IL-4 (19). We identified two main clades of H-IPSE exemplified by the orthologs IPSE ${ }^{\mathrm{H} 03}$ and IPSE ${ }^{\mathrm{H} 06}$. Importantly, both IPSE ${ }^{\mathrm{H} 03}$ and IPSE ${ }^{\mathrm{H} 06}$ translocate into urothelial cell nuclei (19).

Initial animal experiments with H-IPSE focused on the effect of systemic administration of $\mathrm{H}-$ IPSE $^{\mathrm{H} 06}$ by tail vein injection (17). Tail vein injection of H-IPSE ${ }^{\mathrm{H} 06}$ attenuates ifosfamide-induced bladder hemorrhage in an IL-4 and NLS-dependent

41 manner. Furthermore, mice treated with $\mathrm{H}-\mathrm{IPSE}^{\mathrm{H} 06}$ prior to ifosfamide exposure

42 demonstrated fewer spontaneous pain behaviors and had a higher threshold for evoked pain responses. We speculated that direct injection of IPSE into the bladder wall would

44 have multiple advantages over intravenous injection, including avoidance of side effects caused by systemic administration (although none have been identified to date), and 
bioRxiv preprint doi: https://doi.org/10 1101/400424; this version posted August 25, 2018. The copyright holder for this preprint (which was not certified by peer review) is the author/funder, who has granted bioRxiv a license to display the preprint in perpetuity. It is made available under aCC-BY-NC 4.0 International license.

47 to determine whether direct bladder wall injection of $\mathrm{H}$-IPSE ${ }^{\mathrm{H} 03}$ attenuates bladder

48 inflammation, voiding dysfunction and pain in a mouse model of hemorrhagic cystitis. 


\section{Materials and Methods}

Mice

Six to 8-week-old female C57BL/6 mice (Charles River Laboratories, Wilmington, MA) were housed in cages with free access to water and standard chow and 12 hour light-dark cycles. Mice were acclimated for at least 7 days prior to experimentation. The animal protocol was approved by the Institutional Animal Care and Use Committee at the Biomedical Research Institute (Rockville, MD). Our institutional animal care and use committee guidelines follow the U.S. Public Health Service Policy on Human Care and Use of Laboratory Animals.

\section{Bladder wall injections}

Mice were anesthetized with $2 \%$ continuous isoflurane on a heating pad. Procedures were performed using sterile technique. For pain control, $0.1 \mathrm{mg} / \mathrm{kg}$ buprenorphine and $0.1 \mathrm{mg} / \mathrm{kg}$ bupivacaine were injected subcutaneously. A midline laparotomy was performed sharply and the bladder delivered through the incision. Mice were divided into 3 groups receiving sham, control or IPSE. A 30-gauge needle was used to inject a 1:1 v/v mixture of Low Growth Factor Matrigel (Corning, Corning, New York) and PBS containing $25 \mu \mathrm{g}$ mouse albumin (control) or $25 \mu \mathrm{g}$ H-IPSE (IPSE) (Figure 1). Sham mice received a midline laparotomy only. Incisions were closed in 2 layers using 5-0 Vicryl on the abdominal wall and 5-0 silk to close skin. Bacitracin was applied to the incision. The mice were recovered on a heating pad. Twenty-four hours later mice were injected with $400 \mathrm{mg} / \mathrm{kg}$ ifosfamide (Sigma-aldrich, St. Louis, MO). Mice who received anti-IL4 antibody (inVivoMab 11B11, BioXcell, West Lebanon, NH) 
24 received $10 \mathrm{ng}$ by intraperitoneal (IP) injection 30 minutes before ifosfamide. Control

25 mice received IP injections of phosphate-buffered saline (PBS). At 12 hours, mice were

26 euthanized, bladders were removed and weighed. Bladders were then subjected to

27 additional analysis detailed below.

28 Tail vein injections

Mice were anesthetized with $2 \%$ continuous isoflurane on a heating pad. A 30 gauge needle was used to inject PBS containing $25 \mu \mathrm{g}$ mouse albumin or $25 \mu \mathrm{g}$ -

31 IPSE $^{\mathrm{H} 03}$ (IPSE) in PBS. The mice were recovered on a heating pad. Twenty-four hours

32 later mice were injected with $400 \mathrm{mg} / \mathrm{kg}$ ifosfamide (Sigma-aldrich, St. Louis, MO). Mice

33 who received anti-IL4 antibody (inVivoMab 11B11, BioXcell, West Lebanon, NH)

34 received $10 \mathrm{ng}$ by intraperitoneal (IP) injection 30 minutes before ifosfamide. Control

35 mice received IP injections of phosphate-buffered saline (PBS). At 12 hours, mice were

36 euthanized, bladders were removed and weighed. Bladders were then subjected to

37 additional analysis detailed below.

38

Recombinant IPSE protein

Recombinant IPSE protein was generated as previously described $(1,2)$. One milligram of plasmid DNA was purified using a GeneElute HP endotoxin-free plasmid Maxiprep kit (Sigma-Aldrich), and incubated with $3 \mathrm{mg}$ linear $25 \mathrm{kDa}$ polyethylenimine (PolySciences, Warrington, PA) at $1 \mathrm{mg} / \mathrm{mL}$. Finally, the plasmid was diluted in $10 \mathrm{~mL}$ sterile PBS for each transfection in 1L. Human embryonic kidney 293-6E cells (7) expressed secreted recombinant protein for 5 days in suspension culture using FreeStyle 293 Medium (Thermo Fisher Scientific, Waltham, MA, USA) (Figure 2A). 
46 Protein was purified over $10 \mathrm{~mL}$ Ni-NTA resin (Qiagen, Germantown, MD, USA),

47 washed with $25 \mathrm{mM}$ imidazole PBS, $\mathrm{pH}$ 7.4, and eluted with $300 \mathrm{mM}$ imidazole PBS, $\mathrm{pH}$

7.4 containing $50 \mathrm{mM}$ arginine. Eluted protein was concentrated with an Amicon Ultra

49 Centrifugal Filter Unit (EMD Millipore, Billerica, MA, USA) followed by purification with a

50 Hiload 16/600 Superdex 200 Column (GE Healthcare, Waukesha, WI, USA). Nuclear

51 localization mutants were generated using site-directed mutagenesis. These mutants

52 (124-PKRRRTY-130 to 124-PKAAATY) disrupted the C-terminal NLS (NLS; H-

53 IPSE $^{\mathrm{H} 03 \mathrm{NLS}}$ ) (2). To decrease the risk of pyrogen contamination, FPLC machines and

54 Hiload columns were cleaned with $0.5 \mathrm{M} \mathrm{NaoH}$ for greater than 2 hours of continuous

55 flow and then washed with PBS, $\mathrm{pH} 7.4$.

56

57

58

59

60

61

62

\section{SDS-PAGE and Western blotting}

Purified protein was separated on $4-20 \%$ gradient gels by SDS-PAGE in $15 \mu \mathrm{L}$ aliquots (Mini-Protean TGX Precast Gels, Biorad). Separated proteins were then transferred to a $0.2 \mu \mathrm{M}$ nitrocellulose membranes. Membranes were incubated in blocking buffer for 1 hour (5\% [wt/vol] dried skim milk, 0.01\% [vol/vol] Tween 20, and Tris-buffered saline [TBS]) on a shaker at room temp. Primary antibody was mouse antiHis (GE-Healthcare) diluted at 1:500 and incubated overnight at $4^{\circ} \mathrm{C}$ followed by washing in TBS containing $1 \%$ Tween 20 for $5 \mathrm{~min} \times 3$. Membranes were then incubated with secondary antibody--HRP-conjugated anti-mouse IgG (Sigma-Aldrich) -for 1 hour at room temperature followed by 3 additional washes. Imaging was performed with chemiluminesence-luminol reagent $\left(3 \mu \mathrm{L}\right.$ of $30 \% \mathrm{H}_{2} \mathrm{O}_{2}, 0.1 \mathrm{Tris}-\mathrm{HCl}[\mathrm{pH}$ 8.0], 2.5 $\mathrm{mM}$ luminol, and $400 \mu \mathrm{M}$ coumaric acid) on a Fuji LAS4000 imager.

Basophil activation with recombinant M-IPSE, H-IPSE ${ }^{\mathrm{H} 03}$ and H-IPSE ${ }^{\mathrm{H} 06}$ 
Basophil activation was quantified as previously described (23). RS-ATL8 cells were

71 cultured in $10 \mathrm{~mL}$ MEM (GIBCO, USA), supplemented with 5\% vv v/v heat-inactivated

72 FCS (GIBCO, USA), $100 \mathrm{U} / \mathrm{mL}$ penicillin, and $100 \mu \mathrm{g} / \mathrm{mL}$ streptomycin (Sigma, UK) and

732 mM L-glutamine (Sigma, UK). Medium was changed every 2-3 days. Cells were 74 grown in $75 \mathrm{~cm}^{2}$ flasks at $37^{\circ} \mathrm{C}$ in a humidified atmosphere with $5 \%$ carbon dioxide. 1

$75 \mathrm{mg} / \mathrm{mL}$ G418 (Fisher ThermoScientific, UK) and $600 \mu \mathrm{g} / \mathrm{mL}$ hygromycin B (Invitrogen, 76 Paisley, UK) were used to maintain expression of human FcERI genes and NFAT77 luciferase, respectively. Prior to testing, cells were incubated overnight with M-IPSE, H78 IPSE $^{\mathrm{H} 03}$ or $\mathrm{H}^{-I P S E}{ }^{\mathrm{H} 06}$ at concentrations ranging from 5 to $5000 \mathrm{ng} / \mathrm{mL}$. Luciferase assays were performed with ONE-Glo Luciferase Assay System (Promega, UK), following the manufacturer's instructions. The luciferase substrate was added and

81 chemiluminescence was measured using an Infinite M200 microplate reader (Tecan, 82 Männedorf, Switzerland) within 30 minutes.

Pain assessment

Visceral pain scores were assigned as previously described (10). The observer was blinded to mouse treatment assignments prior to assessments. Mice were placed in clean cages and acclimated for $30 \mathrm{~min}$. For spontaneous pain scoring, mice were observed for 60 seconds and given a cumulative spontaneous pain score based on the following: (0) - normal; (1) - piloerection; (2) - labored breathing; (3) - ptosis; (4) -

89 licking of abdomen (not grooming); (5) - rounded back. The maximum possible visceral 90 pain score is 15. Pain scores were collected at baseline (prior to bladder wall injection), 91 and 10 hours after ifosfamide was administered. 
92

\section{Von Frey filament testing}

Evoked pain scores were collected in a blinded fashion to assess for referred hyperalgesia. We adopted the up-down approach as previously described $(6,13)$. An electronic Von Frey filament (BioSeb, Pinellas Park, Florida) was applied to the right hind footpad of the mouse for 5 seconds until the mouse displayed rapid withdrawal of the paw, jumping, or licking of the paw. The 50\% withdrawal threshold was then calculated from an average of 3 measurements. Results are tabulated as the difference between baseline and post-ifosfamide values.

\section{Voided Spot on Paper Assay}

Voided spot on paper assays were performed as previously described $(1,8,11$, 25). Mice were placed in individual cages 2 hours after ifosfamide or PBS administration. Whatman paper was cut to the dimensions of the cage floor. The paper was covered with wire mesh to prevent mice from tearing or ripping the paper. Food was provided ad libitum in the form of regular chow. Water was not provided to prevent fluid dripping onto the paper and causing data loss or artifact. Mice were placed under quiet conditions for 4 hours. They were then returned to normal housing conditions after completion of the experiment. The pieces of Whatman paper were converted to tiff images using UV transillumination (Bio-Rad, Hercules, CA). Image analysis was performed with ImageJ Fiji (https://fiji.sc/). Corner voiding was assessed by assigning $5 \%$ of the total paper area to each corner. Central voiding was assessed by assigning $40 \%$ of the total area to the center of the filter paper.

\section{In vitro proliferation assays}


114 MB49 cells were counted and plated with equal numbers of cells in each well. $\mathrm{H}$ -

115 IPSE $^{\mathrm{H} 03}$ or H-IPSE ${ }^{\mathrm{H} 03 \mathrm{NLS}}$ were added to the cell media at the following concentrations:

$1160.0655 \mathrm{pmol}(1 \mathrm{ng} / \mathrm{ml}), 0.655 \mathrm{pmol}(10 \mathrm{ng} / \mathrm{ml}), 6.55 \mathrm{pmol}(100 \mathrm{ng} / \mathrm{ml}), 65.5 \mathrm{pmol}(1000$

$117 \mathrm{ng} / \mathrm{ml}$ ), or PBS for control. 5-(and 6)-Carboxyfluorescein diacetate succinimidyl ester

118 (CFSE) assays were then performed according to manufacturer's instructions

119 (Thermofisher Scientific, Waltham, MA). One $\mathrm{mL}$ of a single cell suspension for each

120 experimental condition was then acquired on a BD FACSCanto II machine (BD

121 Biosciences, San Jose, CA). Flow cytometric analysis was performed using FlowJo

122 software (Ashland, OR).

123 Statistical analysis

124

125 One-way ANOVA or Student's t-test were utilized as appropriate. Post hoc testing was 126 performed with Bonferroni test. A p-value of less than 0.05 was considered statistically 127 significant. 
1 Results

2 Recombinant H-IPSE ${ }^{\mathrm{H} 03}$ and H-IPSE ${ }^{\mathrm{H} 06}$ proteins activate IgE-bearing basophils in

3 vitro

We previously demonstrated that M-IPSE activates basophils in vitro through NF-

5 AT (23). This pathway is implicated in basophil and mast cell expression of IL-4, which

6 we have observed in vivo in mice administered H-IPSE ${ }^{\mathrm{H} 06}$ (17). Moreover, we have also

7 noted that ifosfamide-challenged mice given $\mathrm{H}$-IPSE ${ }^{\mathrm{H} 06}$ are protected from several

8 pathogenic aspects of hemorrhagic cystitis in an IL-4-dependent fashion (17). Thus, we

9 sought to demonstrate that $\mathrm{H}_{-}$IPSE $^{\mathrm{H} 03}$ and $\mathrm{H}$-IPSE ${ }^{\mathrm{H} 06}$, which are both $S$. haematobium

10 orthologs of M-IPSE, also stimulate IL-4-associated reporter gene expression in vitro.

11 We first purified recombinant $\mathrm{H}-$ IPSE $^{\mathrm{H} 03}$ and $\mathrm{H}-$ IPSE $^{\mathrm{H} 06}$ from transfected HEK293-6A

12 cells. Western blots identified a band with a molecular weight of 38-40 kDa which

13 corresponds to the homodimeric H-IPSE structure (Figure 2A). Recombinant H-IPSE ${ }^{\mathrm{H} 03}$

14 and H-IPSE ${ }^{\mathrm{H} 06}$ protein was then incubated with IgE-loaded basophils. This resulted in

15 NF-AT activation, which is associated with IL-4 secretion in basophils (Figure 2B).

16 Having confirmed that $\mathrm{H}_{\text {-IPSE }}{ }^{\mathrm{H} 03}$ triggers IL-4-associated pathways in cultured

17 basophils, we next sought to determine the therapeutic efficacy of $\mathrm{H}_{-1 P S E}{ }^{\mathrm{H} 03}$ in the mouse model of ifosfamide-induced hemorrhagic cystitis.

19 H-IPSE ${ }^{\mathrm{H} 03}$ dampens chemotherapy-induced increases in bladder wet weight

We assessed for an increase in bladder wet weight caused by hemorrhage,

21 edema and cellular infiltration following ifosfamide injection. Ifosfamide administration

22 caused a statistically significant increase in bladder wet weight compared to controls

23 (Figure 2A, 2B; $n=8, p<0.001) \mathrm{H}_{-} \mathrm{IPSE}^{\mathrm{H} 03}$ bladder wall injection significantly reversed the 
24 increase in bladder wet weight caused by ifosfamide in bladder wall injected mice but

25 not mice that received tail vein injection ( $p=0.02$ and N.S., respectively). The beneficial

26 effect of IPSE on bladder wet weight was reversed by anti-IL4 antibody $(p<0.001)$.

27 However, IPSE ${ }^{\text {H03NLS }}$ also ameliorated ifosfamide-induced increases in bladder wet

28 weight, regardless of mode of administration, suggesting that the therapeutic effect of

29 IPSE on bladder wet weight is mediated by IL-4, but not dependent on IPSE

30 translocation into the nucleus.

Tail vein injection results were distinct from bladder wall injection in two ways.

32 After tail vein $\mathrm{H}$-IPSE ${ }^{\mathrm{H} 03}$ injection bladder wet weights decreased but remained

33 significantly higher than non-ifosfamide-exposed controls (Figure 2B; $\mathrm{p}=0.03$ ).

34 Furthermore, administration of $\mathrm{H}^{-I P S E^{N L S}}$ to ifosfamide-treated mice demonstrated a

35 downward trend in bladder wet weight that was not significant compared to mice given

36 only ifosfamide.

$37 \mathrm{H}-\mathrm{IPSE}^{\mathrm{H} 03}$ abrogates evoked pain responses in chemotherapy-treated mice

We next sought to determine whether H-IPSE ${ }^{\mathrm{H} 03}$ administration had an effect on

39 ifosfamide-induced bladder pain. We first measured referred hyperalgesia using von

40 Frey filament testing. Mice injected with ifosfamide had greater evoked pain responses

41 than those of control mice (Figure 3). $\mathrm{H}^{-I P S E}{ }^{\mathrm{H} 03}$ bladder wall injection increased the

42 withdrawal threshold, i.e., reversed allodynia caused by ifosfamide injection $(p<0.05)$.

43 When neutralizing anti-IL-4 antibody was co-administered with $\mathrm{H}-$ IPSE ${ }^{\mathrm{H} 03}$, the protective

44 effect of $\mathrm{H}-I P S E^{\mathrm{H} 03}$ was attenuated $(\mathrm{p}<0.05)$. Likewise, injection of $\mathrm{H}$-IPSE ${ }^{\mathrm{H} 03 \mathrm{NLS}}$, which

45 cannot translocate to the nucleus, also featured a decreased analgesic effect compared 
46 to IPSE $^{\mathrm{H} 03}(\mathrm{p}<0.05)$. H-IPSE ${ }^{\mathrm{H} 03}$ had no effect on referred hyperalgesia when

47 administered via tail vein injection (data not shown)

48

49

50

51

52

53

54

55

56

57

67

\section{H-IPSE ${ }^{\mathrm{H03}}$ \\ patterns in mice}

does not significant

Mice are prey animals and preferentially void in the corner of their enclosures as a predator avoidance strategy. We assessed for voiding dysfunction caused by ifosfamide based on the percentage of overall voids in the corners of cages. When mice received ifosfamide, the percentage of corner voids was significantly decreased (Figure 4A). H-IPSE ${ }^{\mathrm{H} 03}$ increased the frequency of corner voiding in the presence of ifosfamide, but this was not a statistically significant finding. Administration of a-IL4 antibody reversed the effect of $\mathrm{H}$-IPSE ${ }^{\mathrm{H} 03}$ on corner voiding and was not significantly different from ifosfamide treatment $(p=0.07$ vs. control).

Ifosfamide administration non-significantly increased the percentage of voids in the central area of cages (Figure 4B). H-IPSE ${ }^{\mathrm{H} 03}$, a-IL4 antibody or H-IPSE ${ }^{\mathrm{H} 03 \mathrm{NLS}}$ did not have a significant effect on central voiding. H-IPSE ${ }^{\text {H03NLS }}$-treated mice were not significantly different from ifosfamide-treated or control mice. Tail vein injection of $\mathrm{H}$ IPSE $^{\mathrm{H} 03}$ did not significantly improve or alter voiding patterns in ifosfamide-treated mice (Data not shown).

\section{H-IPSE ${ }^{\mathrm{H} 03}$ promotes proliferation of urothelial cells in vitro}

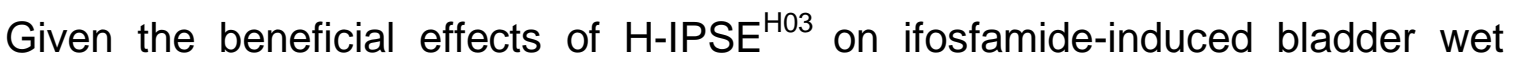
weight increases and pain, as well as prior data indicating a direct effect of $\mathrm{H}$-IPSE ${ }^{\mathrm{H} 03}$ on urothelial cells (17), we assessed the effect of $\mathrm{H}$-IPSE ${ }^{\mathrm{H} 03}$ on urothelial cell 
68 proliferation by co-incubating $\mathrm{H}-\mathrm{IPSE}^{\mathrm{H} 03}$ with the MB49 (mouse urothelial) cell line. $\mathrm{H}$ -

69 IPSE $^{\mathrm{H} 03}$ significantly increased cell proliferation over two successive daughter cell

70 generations compared to controls (Figure $5 A ;{ }^{*} p<0.05,{ }^{* *} p<0.01,{ }^{* *} p<0.0001 ; n=8$ ).

71 This held true across a range of $\mathrm{H}-I P S E^{\mathrm{H} 03}$ concentrations. In contrast, co-incubation of

72 cells with H-IPSE ${ }^{\text {HO3NLS }}$ did not cause increased proliferation over that of controls (Figure

$735 B)$. 


\section{Discussion}

Hemorrhagic cystitis is a common sequela of alkylating chemotherapy, affecting

3 up to $40 \%$ of patients who receive ifosfamide or cyclophosphamide (14). Once

4 established, hemorrhagic cystitis is a challenging-to-manage entity characterized by

5 widespread bladder inflammation and leading to hematuria, dysuria, small volume

6 voids, urinary frequency, and bladder spasms. Currently available medical therapy,

7 MESNA, has a narrow therapeutic window as it can only be administered immediately

8 before and during chemotherapy. MESNA can cause hypersensitivity reactions and is

9 ineffective in treating hemorrhagic cystitis once it has been established $(2,21,22)$.

10 Therefore, novel therapies need to be developed to fulfill this unmet need.

One source of new drugs for hemorrhagic cystitis may be derived from

12 Schistosoma haematobium. Urogenital schistosomiasis is a parasitic disease in which

13 Schistosoma haematobium worms lay eggs in the bladder and other pelvic organs.

14 Deposited eggs must traverse the host bladder wall in order to be released in the urine.

15 Although urogenital schistosomiasis itself causes a form of hemorrhagic cystitis,

16 hematuria can be variable or even absent (24). We reasoned that host

17 immunomodulation by $S$. haematobium egg products allow the parasite to complete its

18 life cycle without causing severe morbidity to its host, including hemorrhagic cystitis

19 (10). Specifically, we postulated that $S$. haematobium eggs can accomplish this by secreting H-IPSE orthologs in order to modulate the host immune response.

In a prior study we demonstrated the clinical potential of exploiting the anti-

22 inflammatory and analgesic properties of $\mathrm{H}$-IPSE ${ }^{\mathrm{H} 06}$ (17). A single intravenous dose of 
23 H-IPSE ${ }^{\mathrm{H} 06}$ was superior to MESNA in alleviating bladder hemorrhage in ifosfamide-

24 treated mice (17).

Clinical translation of $\mathrm{H}$-IPSE ${ }^{\mathrm{H} 06}, \mathrm{H}-\mathrm{IPSE}^{\mathrm{H} 03}$, and other IPSE orthologs will require large-scale recombinant protein production. Herein we show that $\mathrm{H}$-IPSE ${ }^{\mathrm{H} 03}$ and $\mathrm{H}$ -

27 IPSE $^{\mathrm{H} 06}$ can be purified from mammalian HEK293T-6A cells. Furthermore, we 28 demonstrate that, like M-IPSE, H-IPSE ${ }^{\mathrm{H} 03}$ and $\mathrm{H}$-IPSE ${ }^{\mathrm{H} 06}$ trigger IgE-bearing basophil NF-AT activation in vitro, which in turn is linked to IL-4 secretion. H-IPSE ${ }^{\mathrm{H} 03}$ injected into

30 the mouse bladder wall attenuates ifosfamide-induced increases in bladder wet weight

31 in an IL-4 and NLS-dependent fashion. This suggests that H-IPSE ${ }^{\mathrm{H} 03}$ reduces

32 ifosfamide-induced edema, cellular infiltration, and/or hemorrhage (pathologic processes which can increase bladder wet weight). When $\mathrm{H}$-IPSE ${ }^{\mathrm{H} 03}$ was administered via tail vein, ifosfamide-induced increases in bladder wet weight were unaffected.

35 Unsurprisingly, there was neither an IL-4-dependent nor nuclear translocationdependent effect compared to controls. This is consistent with our prior report that

37 intravenous administration of $\mathrm{H}-$ IPSE $^{\mathrm{H} 06}$ did not affect ifosfamide-mediated increases in bladder wet weight (17). There are several possible explanations for these differences

39 in effects of bladder wall versus intravenous injections. For instance, bladder wall injections themselves may cause an increase in hemorrhage, and bladder mass due to

41 the added weight of the matrigel. This may make it more difficult to discern weight 42 differences between groups when compared to tail vein injection. Furthermore, bladder wall injection of $\mathrm{H}$-IPSE ${ }^{\mathrm{H} 03}$ may result in high local concentrations but low systemic

44 levels. We have previously reported that peripheral basophils may play a role in IPSE'S 45 therapeutic effects in hemorrhagic cystitis (17). Recruitment of circulating basophils to 
46 the site of inflammation and subsequent IL-4 release may be dependent on the action of

47 H-IPSE outside of the bladder. Conversely, it is possible that the higher local H-IPSE ${ }^{\mathrm{H} 03}$ concentrations achieved by bladder wall injection may more effectively activate bladder mast cells, basophils, and other cell types critical for therapeutic effects.

Another explanation for the different phenotypes observed between H-IPSE ${ }^{\mathrm{H} 03}$

51 and $\mathrm{H}-\mathrm{IPSE}^{\mathrm{H} 06}$ is that variations in the sequence, and therefore, function of IPSE

52 proteins have evolved such that different orthologs of H-IPSE are secreted to perform

53 different host-modulatory functions. Both orthologs of H-IPSE are homologous to M-

54 IPSE in that they both conserve the C-terminal nuclear localization sequence as well as

557 cysteines which are responsible for forming disulfide bonds to create a homodimeric structure (19). Characterization of sequence/structure-function relationships of individual orthologs of H-IPSE is the subject of continued investigation.

Referred hyperalgesia is a unique feature of visceral pain which causes normally non-painful stimuli to feel painful, even in anatomically distant locations. Cyclophosphamide/ifosfamide administration in rodents is a well-established model of referred hyperalgesia (3-5). We have previously reported that intravenous delivery of H-IPSE ${ }^{\text {H06 }}$ alleviates visceral and referred pain in ifosfamide-treated mice (17). In a

63 similar fashion, bladder wall-injected $\mathrm{H}_{-1 P S E}{ }^{\mathrm{H} 03}$ alleviated referred hyperalgesia in an IL-4 and NLS-dependent fashion. Post-operative pain did not affect the differences 65 observed with $\mathrm{H}-\mathrm{IPSE}^{\mathrm{H} 03}$ administered via bladder wall injection, as we were able to demonstrate a statistically significant increase in pain threshold (i.e., decreased referred 67 hyperalgesia) in ifosfamide-treated mice who received $\mathrm{H}-\mathrm{IPSE}^{\mathrm{H} 03}$. This suggests that 
pain. Tail vein injection of $\mathrm{H}-$ IPSE $^{\mathrm{H} 03}$ did not result in a significant difference between treatment groups (data not shown).

The voided spot on paper assay is a well-established, reliable model to assess lower urinary tract function in mice $(1,8,11,25)$. The characteristic voiding patterns of C57BL/6 mice consist of large volume voids in the corners of cages, whereas bladder injury causes mice to void at non-corner edges or the center of cages (25). We demonstrated that ifosfamide exposure alters voiding behavior by significantly decreasing corner voiding. This was non-significantly reversed by $\mathrm{H}-\mathrm{IPSE}^{\mathrm{H} 03}$ bladder wall injection. Ifosfamide-treated mice tended to void in the central part of the cage, although this was not significant. The voided spot on paper assay results may have been influenced by surgical intervention and accompanying post-operative pain. Tail vein injection of $\mathrm{H}-$ IPSE $^{\mathrm{H} 03}$ did not affect voiding patterns in ifosfamide-treated mice at all (data not shown). We did not allow mice to drink water during the 4 hour duration of assay to avoid possible interference of dripping water with collection of urine on filter paper. Post-operative pain in bladder wall-injected mice, as well as the lack of water access, may have influenced voiding behavior independent of the effects of IPSE.

We previously demonstrated that $\mathrm{H}$-IPSE ${ }^{\mathrm{H} 06}$ induces transcription of uroplakins in the ifosfamide-injured bladder to a degree similar to or greater than MESNA (17). Uroplakins are transmembrane proteins implicated in barrier functions, urothelial proliferation and bladder regeneration (12). Co-incubation of a variety of urothelial cell lines with $\mathrm{H}$-IPSE ${ }^{\mathrm{H} 06}$ significantly increases cell proliferation (data not shown). Moreover, co-incubation of the urothelial cell line MB49 with $\mathrm{H}-$ IPSE $^{\mathrm{H} 03}$ induced a much stronger proliferative response than $\mathrm{H}$-IPSE ${ }^{\mathrm{H} 06}$. The pro-proliferative effect of $\mathrm{H}$-IPSE ${ }^{\mathrm{H} 03}$ 
92 was nuclear localization sequence-dependent. This supports the notion that H-IPSE ${ }^{\mathrm{H} 03}$

93 may upregulate urothelial repair mechanisms through translocation to the nucleus and

94 modulation of gene expression. Future work will be directed towards further quantifying

95 changes in uroplakin and related gene expression induced by $\mathrm{H}$-IPSE ${ }^{\mathrm{H} 03}$.

This study has several limitations. For instance, the mechanism by which IPSE

97 targets and sequesters chemokines is poorly understood. It is possible that IPSE's chemokine-binding properties may play a role in its therapeutic effects in the ifosfamide-

99 injured bladder. Furthermore, we have not elucidated the mechanism by which IPSE exerts its effects outside the bladder. We chiefly included experiments in which IPSE was delivered directly to the tissue of interest. It is unclear how the mechanism of action of $\mathrm{H}$-IPSE ${ }^{\mathrm{H} 03}$ is different when administered in a local versus systemic fashion. For example, basophil and mast cell recruitment to the bladder to release anti-inflammatory IL-4 may be modulated differently based on the concentration of regional and systemic IPSE. Nuclear translocation is an important component of the therapeutic effect of IPSE and we have not yet investigated transcriptional regulation by $\mathrm{H}_{\text {-IPSE }}{ }^{\mathrm{H} 03}$. It is also unclear whether IPSE operates on a transcriptional level or whether there is a posttranslational component to its mechanism of action. These are areas of ongoing work. protein, H-IPSE ${ }^{\mathrm{H} 03}$, to treat hemorrhagic cystitis via bladder wall injection. Because we 111 have found that IPSE modulates the host immune system to dampen inflammation as 112 well as pain responses, we speculate that this protein could potentially be used for 113 broader indications, such as interstitial cystitis and other bladder pain syndromes. 
bioRxiv preprint doi: https://doi.org/10.1101/400424; this version posted August 25, 2018. The copyright holder for this preprint (which was not certified by peer review) is the author/funder, who has granted bioRxiv a license to display the preprint in perpetuity. It is made available under aCC-BY-NC 4.0 International license.

115 


\section{Acknowledgements}

2 We thank H. Gil Rushton and Hans G. Pohl for their support of urologic basic science

3 research at Children's National Medical Center.

\section{Grants}

5 This work was supported by funding from the Margaret A. Stirewalt Endowment and the

6 U.S. National Institutes of Health, National Institutes of Diabetes and Digestive and

7 Kidney Diseases (1R01DK113504). 


\section{References}

1. Ackert-Bicknell CL, Anderson LC, Sheehan S, Hill WG, Chang B, Churchill GA, Chesler EJ, Korstanje R, Peters LL. Aging Research Using Mouse Models. In: Current Protocols in Mouse Biology. John Wiley \& Sons, Inc., p. 95-133.

2. Andriole GL, Sandlund JT, Miser JS, Arasi V, Linehan M, Magrath IT. The efficacy of mesna (2-mercaptoethane sodium sulfonate) as a uroprotectant in patients with hemorrhagic cystitis receiving further oxazaphosphorine chemotherapy. J Clin Oncol 5: 799-803, 1987.

3. Bicer F, Altuntas CZ, Izgi K, Ozer A, Kavran M, Tuohy VK, Daneshgari F. Chronic pelvic allodynia is mediated by CCL2 through mast cells in an experimental autoimmune cystitis model. AJP Ren Physiol 308: F103-F113, 2015.

4. Bon K, Lichtensteiger CA, Wilson SG, Mogil JS. Characterization of cyclophosphamide cystitis, a model of visceral and referred pain, in the mouse: Species and strain differences. J Urol 170: 1008-1012, 2003.

5. Boucher M, Meen M, Codron JP, Coudore F, Kemeny JL, Eschalier a. Cyclophosphamide-induced cystitis in freely-moving conscious rats: behavioral approach to a new model of visceral pain. J Urol 164: 203-8, 2000.

6. Chaplan SR, Bach FW, Pogrel JW, Chung JM, Yaksh TL. Quantitative assessment of tactile allodynia in the rat paw. J Neurosci Methods 53: 55-63, 1994.

7. Delafosse L, Xu P, Durocher Y. Comparative study of polyethylenimines for transient gene expression in mammalian HEK293 and CHO cells. J. Biotechnol. (2016). doi: 10.1016/j.jbiotec.2016.04.028.

8. Fu C-L, Odegaard JI, Herbert DR, Hsieh MH. A Novel Mouse Model of Schistosoma haematobium Egg-Induced Immunopathology. PLoS Pathog 8: e1002605, 2012.

9. Hader JE, Marzella L, Myers RA, Jacobs SC, Naslund MJ. Hyperbaric oxygen treatment for experimental cyclophosphamide-induced hemorrhagic cystitis. $J$ Urol 149: 1617-21, 1993.

10. Hewitson JP, Grainger JR, Maizels RM. Helminth immunoregulation: The role of parasite secreted proteins in modulating host immunity. Mol Biochem Parasitol 167: 1-11, 2009.

11. Hsieh Y-J, Fu C-L, Hsieh MH. Helminth-Induced Interleukin-4 Abrogates Invariant Natural Killer T Cell Activation-Associated Clearance of Bacterial Infection. Infect Immun 82: 2087-2097, 2014. 
13. Leventhal L, Strassle B. A model of cystitis pain in the mouse. Curr Protoc Pharmacol : 1-11, 2008.

14. Lima MVA, Ferreira FV, Macedo FYB, de Castro Brito GA, Ribeiro RA. Histological changes in bladders of patients submitted to ifosfamide chemotherapy even with mesna prophylaxis. Cancer Chemother Pharmacol 59: 643-650, 2007.

15. Macedo FYB, Mourão LTC, Freitas HC, Lima RCP, Wong DVT, Oriá RB, Vale ML, Brito GAC, Cunha FQ, Ribeiro RA. Interleukin-4 modulates the inflammatory response in ifosfamide-induced hemorrhagic cystitis. Inflammation 35: 297-307, 2012.

16. Matz EL, Hsieh MH. Review of Advances in Uroprotective Agents for Cyclophosphamide- and Ifosfamide-induced Hemorrhagic Cystitis. Urology 100: 16-19, 2017.

17. Mbanefo EC, Le L, Pennington LF, Odegaard JI, Jardetzky TS, Alouffi A, Falcone FH, Hsieh MH. Therapeutic exploitation of IPSE, a urogenital parasitederived host modulatory protein, for chemotherapy-induced hemorrhagic cystitis. FASEB J 32: 000-000, 2018.

18. Oguchi T, Funahashi Y, Yokoyama H, Nishizawa O, Goins WF, Goss JR, Glorioso JC, Yoshimura N. Effect of herpes simplex virus vector-mediated interleukin-4 gene therapy on bladder overactivity and nociception. Gene Ther 20: 194-200, 2013.

19. Pennington LF, Alouffi A, Mbanefo EC, Ray D, Heery DM, Jardetzky TS, Hsieh MH, Falcone FH. H-IPSE is a pathogen-secreted host nucleus infiltrating protein (infiltrin) expressed exclusively by theSchistosoma haematobiumegg stage. Infect Immun 85: e00301-17, 2017.

20. Ribeiro R, LimaJunior R, Leite C, Mota J, Macedo F, Lima M, Brito G. Chemotherapy-induced hemorrhagic cystitis: pathogenesis, pharmacological approaches and new insights. J Exp Integr Med 2: 1, 2012.

21. SAKURAI M, SAIJO N, SHINKAI T, EGUCHI K, SASAKI Y, TAMURA T, SANO T, SUEMASU K, JETT JR. The Protective Effect of 2-Mercapto-Ethane Sulfonate (MESNA) on Hemorrhagic Cystitis Induced by High-Dose Ifosfamide Treatment Tested by a Randomized Crossover Trial. Jpn J Clin Oncol 16: 153-156, 1986.

22. Shepherd JD, Pringle LE, Barnett MJ, Klingemann HG, Reece DE, Phillips GL. Mesna versus hyperhydration for the prevention of cyclophosphamideinduced hemorrhagic cystitis in bone marrow transplantation. J Clin Oncol 9: 2016-20, 1991.

23. Wan D, Ludolf F, Alanine DGW, Stretton O, Ali Ali E, Al-Barwary N, Wang X, Doenhoff MJ, Mari A, Fitzsimmons CM, Dunne DW, Nakamura R, Oliveira GC, Alcocer MJC, Falcone FH. Use of Humanised Rat Basophilic Leukaemia Cell Line RS-ATL8 for the Assessment of Allergenicity of Schistosoma mansoni Proteins. PLoS Negl. Trop. Dis. (2014). doi: 10.1371/journal.pntd.0003124. 
24. Watanabe K, Muhoho ND, Mutua WR, Kiliku FM, Awazawa T, Moji K, Aoki Y. Assessment of Voiding Function in Inhabitants Infected with Schistosoma haematobium. J Trop Pediatr 57: 263-268, 2011.

25. Yu W, Ackert-Bicknell C, Larigakis JD, Maclver B, Steers WD, Churchill GA, Hill WG, Zeidel ML. Spontaneous voiding by mice reveals strain-specific lower urinary tract function to be a quantitative genetic trait. AJP Ren Physiol 306: F1296-F1307, 2014. 


\section{Figure Legends}

2

3 Figure 1: Bladder wall injection technique. Mice were anesthetized with inhaled

4 isoflurane. Next their abdomens were depilated and cleaned, injected with local

5 anesthetic, and a midline laparotomy was performed. The bladder was exteriorized,

6 stabilized with a cotton applicator, and its wall injected with a 30 gauge needle.

7 Figure 2: (A) Western blots of purified $\mathrm{H}-$ IPSE $^{\mathrm{H} 03}$ and $\mathrm{H}$-IPSE ${ }^{\mathrm{H} 06}$ proteins demonstrate a

8 prominent band with a molecular weight of approximately 38-40 kDa. (B) Basophil NF-

9 AT activation in response to M-IPSE, $\mathrm{H}$-IPSE ${ }^{\mathrm{H} 03}$ and $\mathrm{H}$-IPSE ${ }^{\mathrm{H} 06}$. Incubation of IPSE with

10 IgE-bearing basophils demonstrates that H-IPSE orthologs induce NF-AT reporter gene expression comparable to M-IPSE.

12 Figure 3: Effect of $\mathrm{H}_{-}$IPSE $^{\mathrm{H} 03}$ on bladder wet weights. Mice received a bladder wall injection $(A)$ or a tail vein injection $(B)$ with or without $\mathrm{H}-\mathrm{IPSE}^{\mathrm{H} 03}$ or a nuclear localization sequence mutant of $\mathrm{H}$-IPSE ${ }^{\mathrm{H} 03}$ (IPSE $_{\mathrm{NLS}}$ ). Twenty-four hours later, mice were injected with PBS (control) or ifosfamide ("ifosfamide" or "ifos"). Some mice received neutralizing anti-IL4 antibody ( $\alpha$ IL4) 30 minutes prior to ifosfamide. Bladders were collected and weighed 12 hours following ifosfamide injection to assess for edema and hemorrhage.

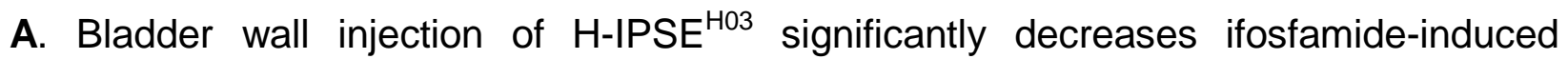
increase in bladder wet weight in an IL-4- but not nuclear translocation-dependent fashion. B. Tail vein injection of $\mathrm{H}-\mathrm{IPSE}^{\mathrm{H} 03}$ non-significantly decreases the ifosfamideinduced increase in BWW in an IL-4 but not NLS-dependent fashion. Plotted data are pooled from 3 experiments. Error bars represent standard deviations. 
23 Figure 4: The effect of IPSE bladder wall injections on evoked pain responses (referred

24 hyperalgesia). H-IPSE ${ }^{\mathrm{H} 03}$ bladder wall injection alleviates allodynia (referred

25 hyperalgesia) associated with hemorrhagic cystitis-associated pain in an IL-4 and NLS-

26 dependent manner. Plotted data are pooled from 3 experiments. $\left({ }^{*} \mathrm{p}=0.04,{ }^{* *} \mathrm{p}=0.02\right.$,

$2{ }^{* * *} \mathrm{p}=0.01$; Bars represent means and one standard deviation)

28 Figure 5: Voiding dysfunction caused by ifosfamide was non-significantly alleviated by bladder wall injections of $\mathrm{H}$-IPSE ${ }^{\mathrm{H} 03}$. Ifosfamide significantly decreased corner voiding (A \& D). H-IPSE ${ }^{\mathrm{H} 03}$ non-significantly restored the percentage of corner voids in ifosfamide-treated mice (E). Administration of neutralizing a-IL4 antibody may reverse

32 the non-significant protective effect of $\mathrm{H}_{-} \mathrm{IPSE}^{\mathrm{H} 03}(\mathrm{~F})$.

Central voiding tended to increase following ifosfamide administration (B). The addition

of H-IPSE ${ }^{\mathrm{H} 03}(\mathrm{E})$, neutralizing a-IL4 antibody $(\mathrm{F})$ or $\mathrm{H}-\mathrm{IPSE}^{\mathrm{H} 03 \mathrm{NLS}}(\mathrm{G})$ did not significantly change the percentage of voiding observed in the center of the cage. Plotted data are pooled from 3 experiments. ${ }^{* *} p<0.01$; error bars represent standard deviations.

Figure 6: $\mathrm{H}-\mathrm{IPSE}^{\mathrm{H} 03}$ co-incubation with $\mathrm{MB} 49$ cells induced proliferation in an NLSdependent fashion. (A) When co-incubated with $\mathrm{H}-\mathrm{IPSE}^{\mathrm{H} 03}$, the number of MB49 cells was markedly increased versus control over 3 generations of cells. Significant increases in proliferation were observed for both low $(0.065 \mathrm{pmol})$ and high concentrations of $\mathrm{H}$ -

41 IPSE $^{\mathrm{H} 03}$ (up to $65.5 \mathrm{pmol}$ ). (B) MB49 cellular proliferation was not increased compared

42 to controls by co-incubation with H-IPSE ${ }^{\text {HO3NLS }}$. 
bioRxiv preprint doi: https://doi.org/10.1101/400424; this version posted August 25, 2018. The copyright holder for this preprint (which was not certified by peer review) is the author/funder, who has granted bioRxiv a license to display the preprint in perpetuity. It is made available under aCC-BY-NC 4.0 International license.

\section{Figure 1}

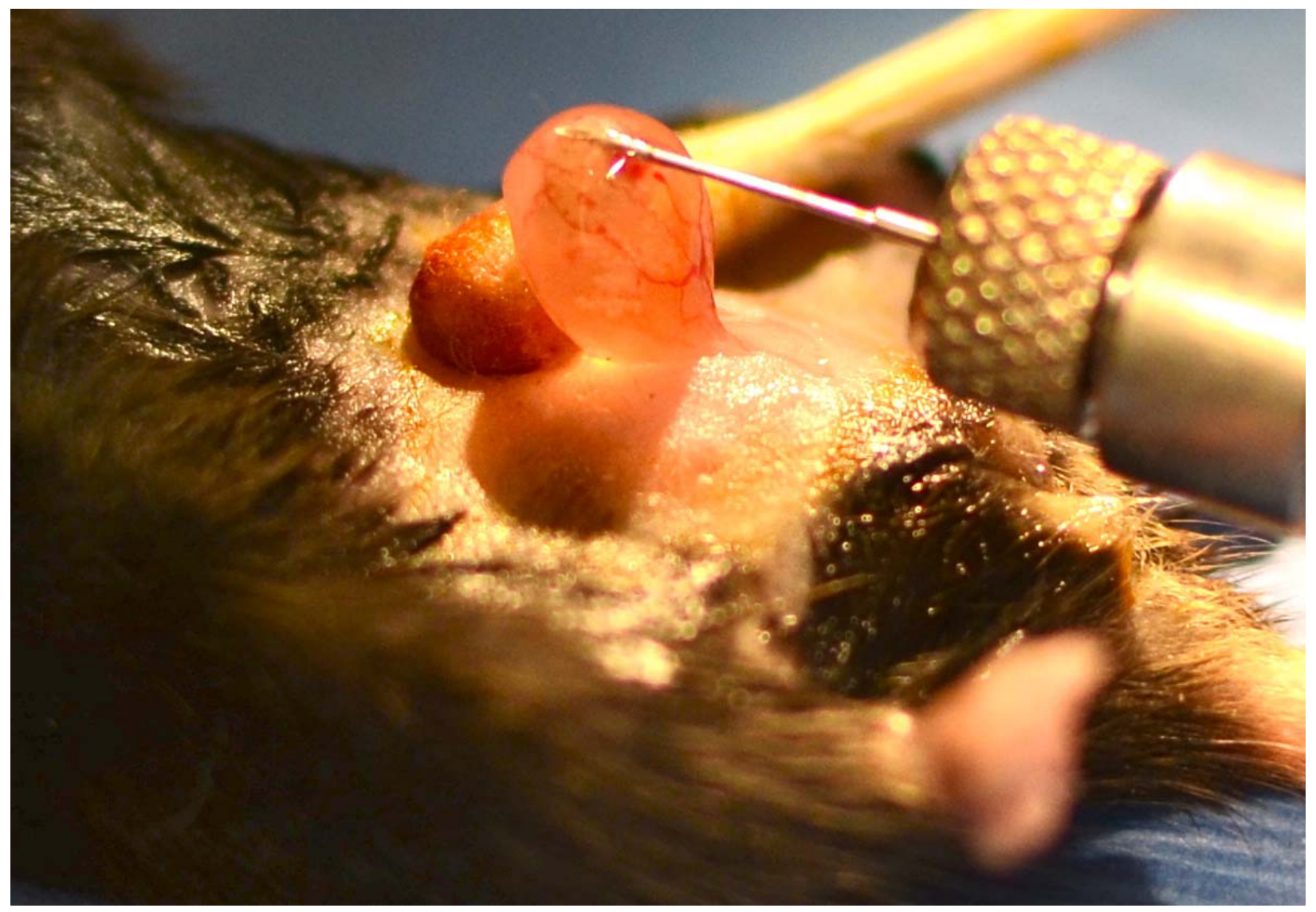


Figure 2

A
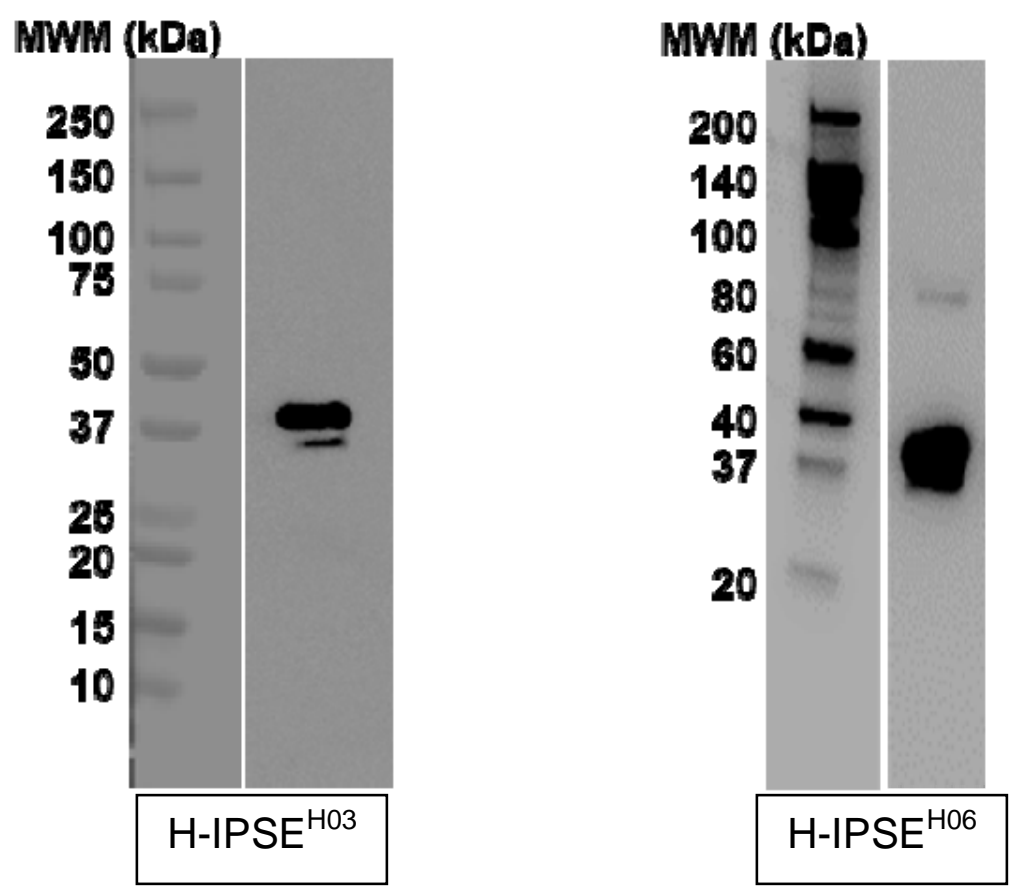

B

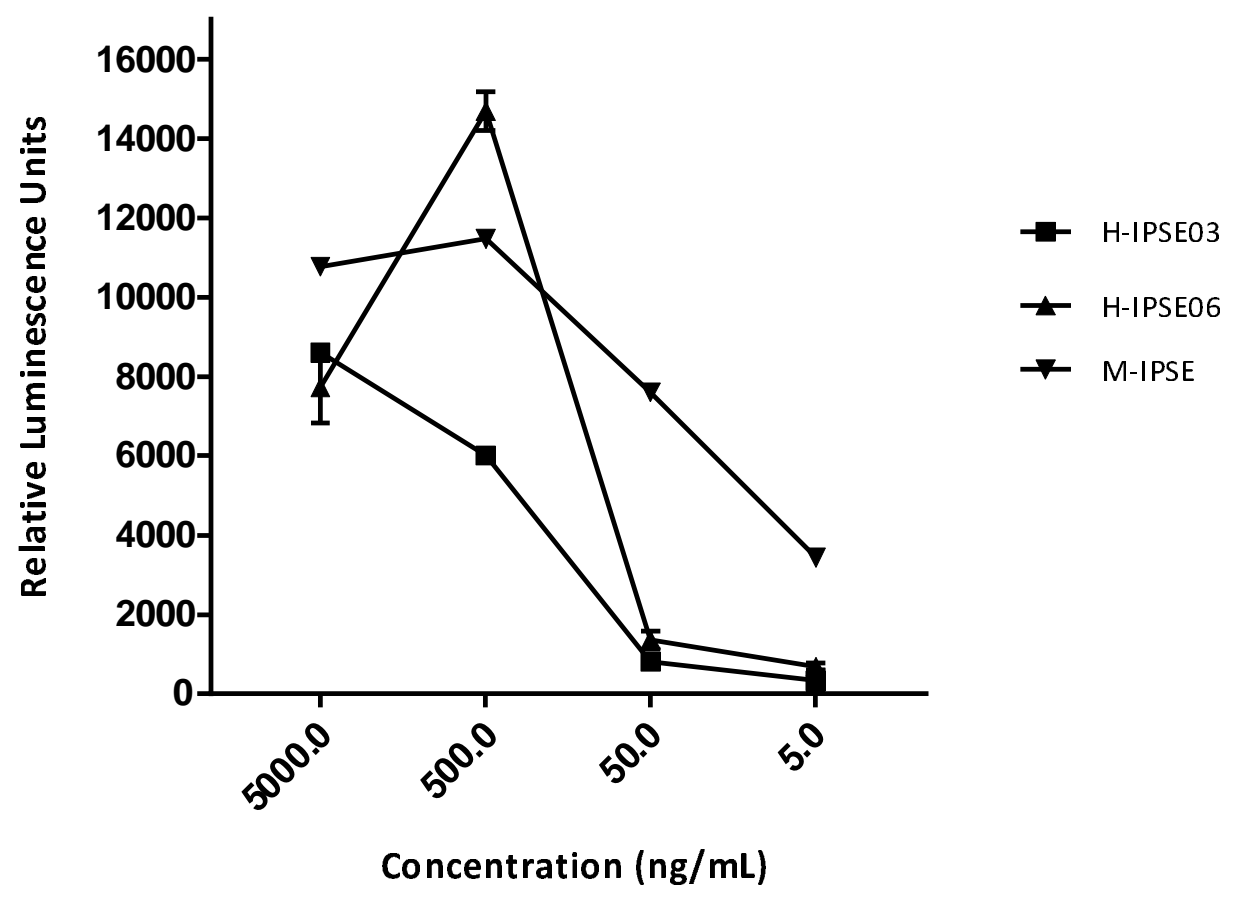


Figure 3

A

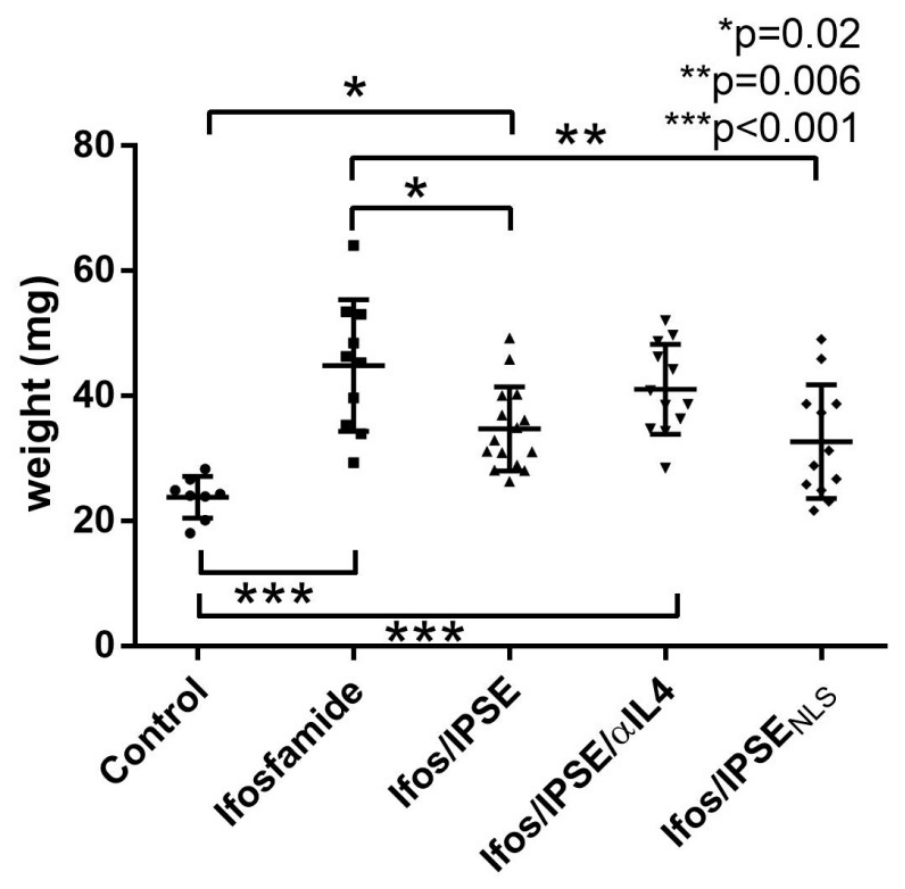

B

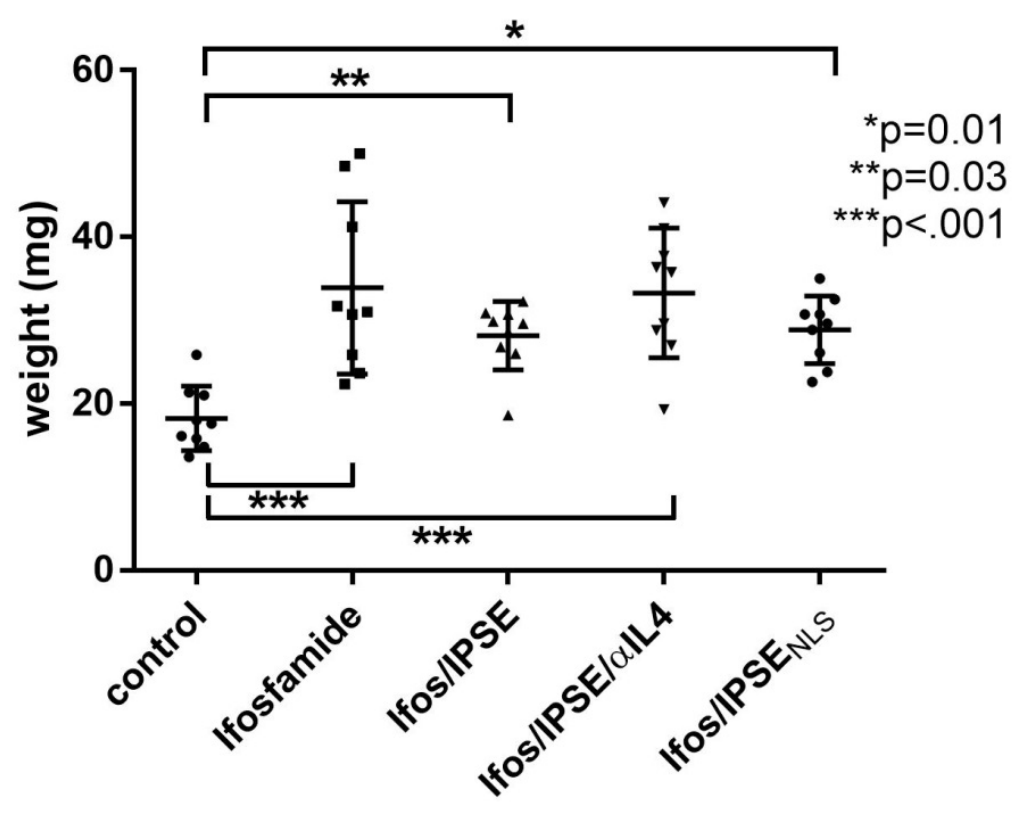


bioRxiv preprint doi: https://doi.org/10.1101/400424; this version posted August 25, 2018. The copyright holder for this preprint (which was not certified by peer review) is the author/funder, who has granted bioRxiv a license to display the preprint in perpetuity. It is made available under aCC-BY-NC 4.0 International license.

\section{Figure 4}

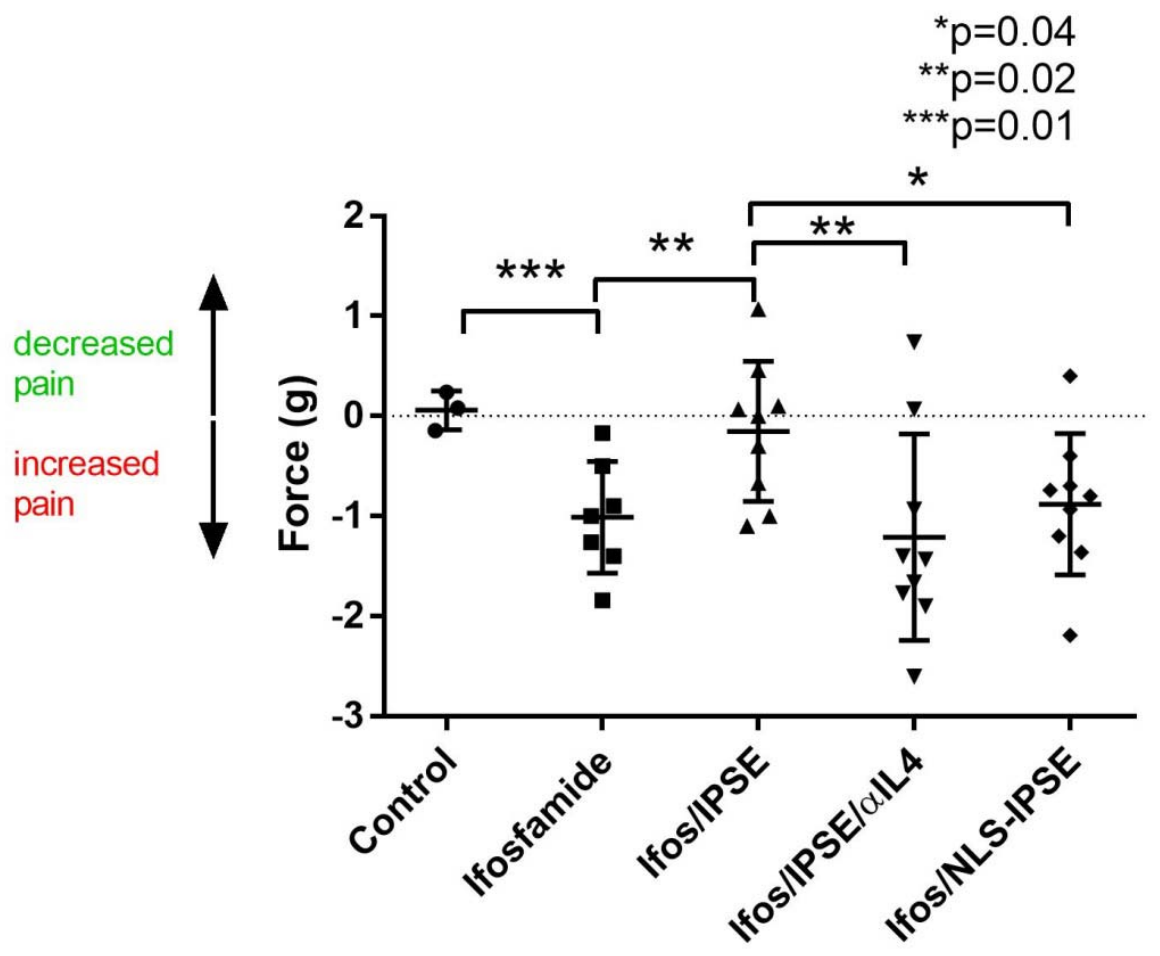


Figure 5
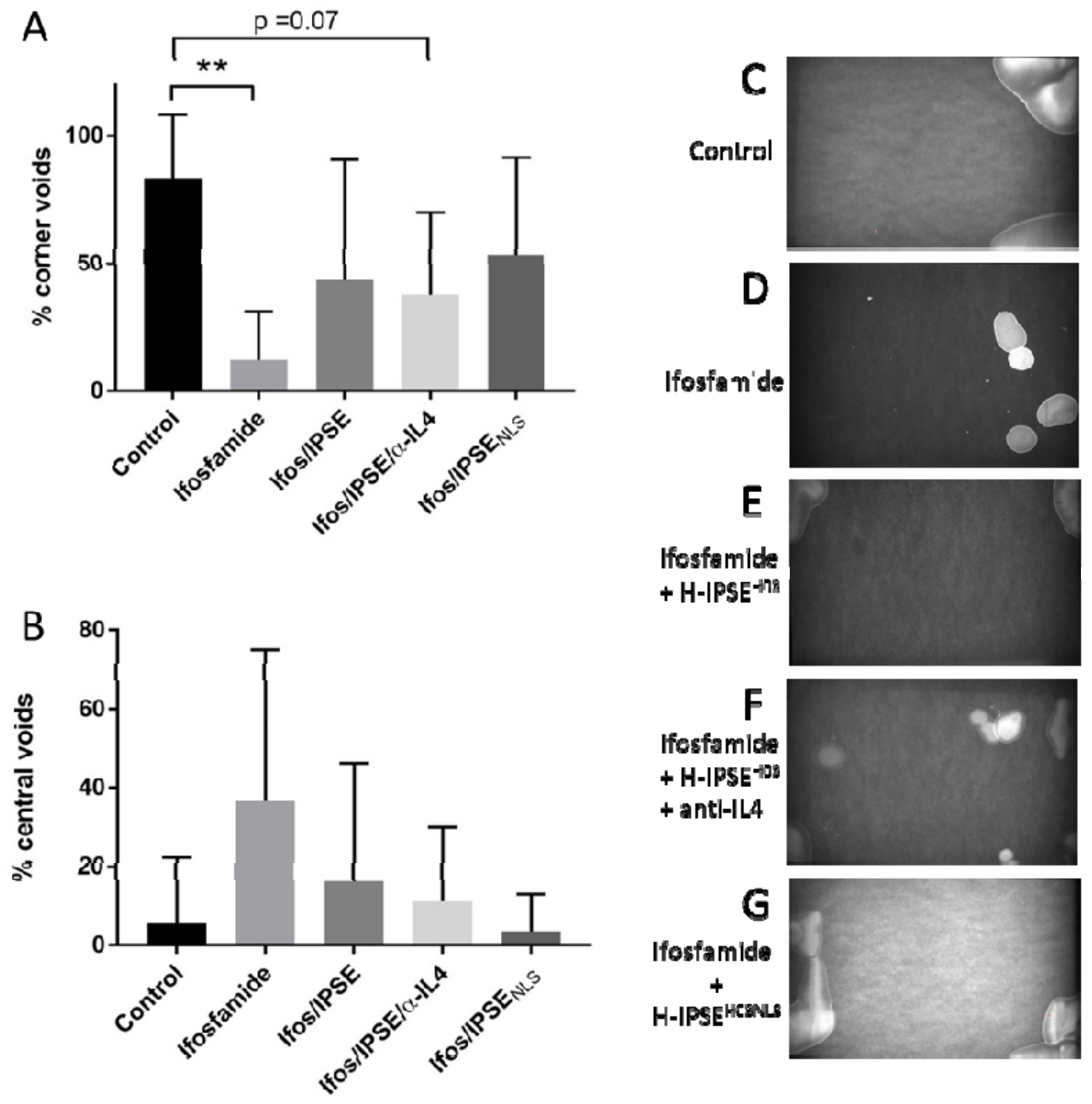
bioRxiv preprint doi: https://doi.org/10.1101/400424; this version posted August 25, 2018. The copyright holder for this preprint (which was not certified by peer review) is the author/funder, who has granted bioRxiv a license to display the preprint in perpetuity. It is made available under aCC-BY-NC 4.0 International license.

Figure 6
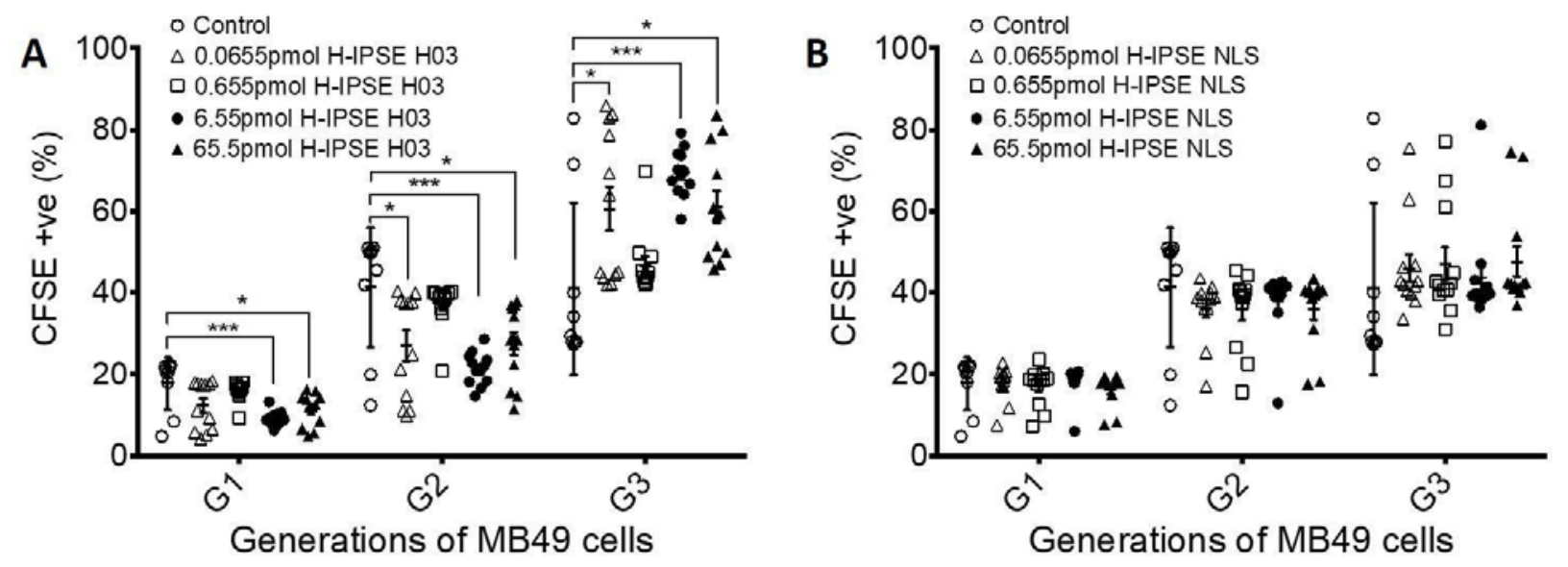